\title{
Effectiveness of Patient Centered Care to Reduce Anxiety Level and Improve Satisfaction in Patients Undergoing Cataract Surgery
}

\author{
Mochammad Sjarifudhin*, Elsye Maria Rosa* \\ * Correspondent Author: msjarifudhin.spm@gmail.com \\ * Master of Hospital Management, Universitas Muhammadiyah Yogyakarta, Yogyakarta, Indonesia
}

\section{N D E X I N G}

Keywords:

Patient Centered Care;

Anxiety;

Satisfaction;

Cataract Surgery;

Kata kunci:

Patient Centered Care;

Kecemasan;

Kepuasan;

Operasi Katarak;

\begin{abstract}
A B S T R AC T
Research on Patient Centered Care (PCC) in cataract patients is still limited, especially those that analyze the effectiveness of PCC in reducing anxiety levels and improving the patient satisfaction. This study was a quasi-experimental pre- and post-test design, which involved 30 treatment respondents and 30 control respondents. The instrument used a SAI questionnaire to measure anxiety and SERVQUAL modifications to measure patient satisfaction. The study was conducted at Nganjuk Eye Clinic in October-November 2018. Analysis of data using paired t-test and independent t-test. The results of difference tests of anxiety levels before and after PCC and difference tests of anxiety levels of the control and PCC group showed the results of sig. 2-tailed $=0,000$. Whereas the difference tests of satisfaction levels between the control and PCC group were obtained sig. 2-tailed = 0.035. The PCC Effect Size obtained strong effects (2.59 and 4.31) in reducing anxiety and average effect (0.56) on improving satisfaction. There were significant differences in the level of anxiety and satisfaction in both groups. The results showed that PCC was very effective in reducing anxiety levels and quite effective in improving the satisfaction on cataract surgery patients.
\end{abstract}

Penelitian tentang Patient Centered Care (PCC) pada pasien operasi katarak masih terbatas, khususnya yang menganalisis efektivitas PCC dalam menurunkan tingkat kecemasan dan meningkatkan kepuasan pasien. Penelitian ini merupakan quasi-experimental pre- and post-test design, yang melibatkan 30 responden intervensi PCC dan 30 responden kontrol. Instrumen penelitian menggunakan kuesioner SAI untuk mengukur kecemasan dan modifikasi SERVQUAL untuk mengukur kepuasan pasien. Penelitian dilakukan di Klinik Mata Nganjuk pada Oktober-November 2018. Analisis data menggunakan paired t-test dan independent t-test. Hasil pengukuran uji beda tingkat kecemasan sebelum) dan sesudah PCC serta uji beda tingkat kecemasan kelompok kontrol dan PCC menunjukkan hasil sig. 2-tailed =0,000. Sedangkan uji beda tingkat kepuasan antara kelompok kontrol dan PCC diperoleh sig. 2-tailed =0,035. Effect Size PCC didapatkan strong effect (2,59 dan 4,31) terhadap penurunan kecemasan dan average effect $(0,56)$ terhadap peningkatan kepuasan. Terdapat perbedaan bermakna tingkat kecemasan maupun kepuasan pada kedua kelompok tersebut. Hasil penelitian menunjukkan bahwa PCC sangat efektif dalam menurunkan tingkat kecemasan dan cukup efektif dalam meningkatkan kepuasan pasien operasi katarak.

(C) 2018 JMMR. All rights reserved

\section{INTRODUCTION}

Cataracts are a major cause of blindness in the world. Cataracts are lens opacities which result in a decrease in visual acuity and disruption in doing work, which causes a significant decrease in quality of life $\stackrel{1-3}{\text {. Senile cataracts }}$ (age related) occur as a result of the irreversible lens protein denaturation $\frac{4,5}{}$.

The World Health Organization (WHO) states that cataracts are a major cause of blindness (35\%) in the world ${ }^{6}$. Cataracts are also the second highest cause of visual impairment $(33 \%)$ in the world after refractive abnormalities $(42 \%)_{-}^{7}$.
Based on the Survey of Rapid Assessment of Avoidable Blindness (RAAB), the main causes of blindness (visual acuity $<3 / 60)$ in Indonesia are cataracts $(71.7 \%)$, followed by posterior segment abnormalities (10.9\%). Cataract $(77 \%)$ is also the most common cause of severe visual impairment (3/60 - 6/60 vision) in Indonesia, followed by refractive abnormalities (10.5\%). Moderate visual impairment (6/18 - 6/60 vision sharpness) in Indonesia is caused by cataracts $(51.2 \%)$, and is followed by refractive abnormalities (36.8\%). The survey conducted at 2014 2016 in 15 provinces in the population in this age of 50 also shows that East Java is the province with the largest prevalence of blindness in Indonesia $(3 \%)^{\frac{8}{}}$. 
Cataracts can only be cured through surgery, by taking a cloudy lens and replacing it with an artificial implanted intraocular lens $\frac{2,6}{6}$. Cataract surgery has now shifted from requiring inpatients to same-day surgery thanks to advances in medical technology, especially in the areas of surgery and better and less invasive anesthesia methods ${ }^{3.5}$. Phacoemulsification is a technique that is now routinely performed (85\%) using very less invasive local / topical anesthesia $9, \underline{10}$.

Cataract surgery is one indicator of achieving the goal of one of the WHO programs, namely Universal Eye Health: 2014-2019 Global Action Plan. The aim of the program is to reduce the number of visual impairments that can be prevented and secure access to rehabilitation centers for patients with visual impairments that cannot be prevented ${ }^{7}$. According to Ramke (2017), cataract surgery is an efficient intervention to restore vision. Cataract surgery can also improve quality of life, time and social status, which ultimately has a positive impact on poverty alleviation $3, \underline{5}$.

Local anesthesia is an anesthetic method that is often used in cataract surgery, because it is a less invasive method with low morbidity. However, cataract surgery under local anesthesia can be a cause of anxiety for patients. Anxiety occurs in most patients with cataract surgery, although there have been developments in surgical techniques and anesthesia methods $\stackrel{9-12}{-}$.

Various studies have been conducted in order to find out the causes of anxiety and the emotional aspects of cataract surgery. Several previous studies have also shown that cataract patients can experience preoperative anxiety, surgery, and postoperatively $\stackrel{9, \underline{11,13}}{\text {. }}$.

Some studies suggest that a patient's lack of understanding of cataract surgery is related to an increase in patient dissatisfaction and anxiety, and reduces patient compliance with surgery-related instructions, which can ultimately increase the risk of complications?

The concept of Patient-Centered Care (PCC) has always evolved and become increasingly widely known. Balint (1969) first defined PCC as a term for understanding patients as unique human beings. During the 20th century, PCC developed into a focus of the health care system that promised an increase in patient satisfaction and health service outcomes. The Institute of Medicine (2001) identifies PCC as a key aspect of quality care $\stackrel{14,15}{\text {. The need }}$ for the importance of PCC has been identified by the Institute of Medicine as one of the six elements of quality health services $\frac{16-18}{}$
PCC has seeped into parts of the health service, but no universally agreed upon consensus regarding the definition of the PCC itself. Most service providers, policy makers, and researchers agree that the PCC represents a paradigm shift from traditional, paternalistic, directed service providers, and focuses on disease to see patients holistically $\underline{15,19-22}$.

PCC can be interpreted as a holistic paradigm, namely looking at individuals as a whole biopsychosocial and physiological. This paradigm seeks to ensure that the needs of individuals who access health care services can be met with respect and responsiveness, and are based on the concepts of value, personal preference, and partnerships in the clinical decision-making process. PCC adopts a contractual view of health services by seeing patients as active participants who must be involved in each decisionmaking process. Participation along with a greater emphasis on communication can create a process of collaboration and decision making that is better than just seeing patients as a passive component of the medical process $\stackrel{22}{=}$. Hobbs (2009) defines PCC as a solution to find patient needs, coordination, individuals who have skills and concerns, and

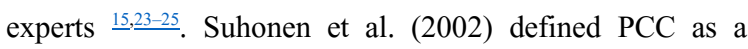
comprehensive care that fulfills every patient's physical, psychological, and social needs $\underset{26}{2}$. The Institute of Medicine (2001) defines PCC as respectful care in order to meet patient preferences, needs, and values, and involve patients in making all clinical decisions $\underline{14,27,28}$.

Several previous studies have stated that PCC can improve the harmonization of health care service provider

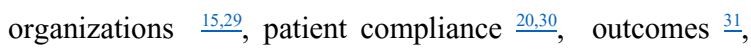
patient satisfaction $\stackrel{32}{2}$, and quality of life $\stackrel{33}{ }$, as well as a decrease in anxiety and mortality ${ }^{24}$ and use of health resources $22,34-38$

In the field of cataract and refractive surgery, PCC is manifested in the form of preoperative assessment, education, informed consent, and management of expectations. Patient education should include basic knowledge of cataracts, the effect of cataracts on vision, and phacoemulsification procedures $\stackrel{39}{-}$. Patient education is one of the dimensions of PCC development, which is very important in preparing patients to take responsibility for operating instructions. The efficient process of information transfer is very important in the preparation of outpatient cataract surgery ${ }^{40}$. Providing sufficient time for the education process and informed consent is very important, because the preoperative expectations of cataract patients have an important role in postoperative satisfaction ${ }_{-}^{41}$ 
Some studies have found that education before cataract surgery can reduce anxiety, speed up return, and increase patient satisfaction, and reduce complications of surgery 10,42 . The patient education is one of the development dimension of the PCC, which is very important in preparing the patient's responsibility to follow the instructions during surgery $\frac{40}{-}$.

By looking that cataract surgery has been promoted by WHO in order to eradicate blindness, by making it as an indicator of achieving the goal of one of the WHO programs, Universal Eye Health: 2014-2019 Global Action Plan ${ }_{-}^{4}$, and the very importance of applying PCC to cataract surgery patients, while research on PCC in cataract surgery patients is still very limited, and have not found in Indonesia, it has aroused researchers to analyze the effectiveness of Patient Centered Care in reducing anxiety levels and improving the satisfaction of cataract surgery patients. Based on this background, the research questions can be formulated as: "Is Patient Centered Care effective in reducing anxiety levels and improving satisfaction of cataract surgery patient?"

\section{RESEARCH METHOD}

The method of this research is quantitative analytical with a quasi-experimental approach pre- and post-test design, to obtain information that approaches results obtained with true-experimental, in circumstances that are not possible to control and / or manipulate all relevant variables. This research was conducted at Ayu Siwi Nganjuk Eye Clinic in October-November 2018.

The sampling technique in this study is total sampling, which is the number of samples equal to the population. This technique is used because according to Sugiyono (2007) the population is less than 100 , the entire population is used as the research sample. The sample of this study amounted to 60 people. The inclusion criteria for this study included: a) adults (age $\geq 18$ years), and b) willing to become respondents. While the exclusion criteria in this study include: a) mental disorders (unable to communicate well), and b) employee of Ayu Siwi Nganjuk Eye Clinic.

This study compared between 2 groups, PCC intervention and control, and compared conditions before and after PCC intervention. The variables measured in this study were anxiety and satisfaction as independent variables. Measuring the level of anxiety using the State Anxiety Inventory (SAI), which consists of 14 items and divided into 2 types of questions, favorable and unfavorable. While the satisfaction level was measured by SERVQUAL modification, which is divided into 5 dimensions: reliability, responsiveness, assurance, empathy, and tangibility .

The researcher began the research by conducting a survey of the Ayu Siwi Eye Clinic which will be used as a place of research. Before starting the research, Researchers will conduct a Focus Group Discussion (FGD) with the professionals at the clinic about the formation of the PCC team and discuss the application of PCC. When a patient is diagnosed with cataracts and meets the sample criteria, the researcher will provide an SAI questionnaire, then direct review of the implementation process of the PCC, and if PCC has been applied, then provide SAI questionnaire once again to the intervention group. The SERVQUAL modification questionnaire will be given to respondents after undergoing cataract surgery.

PCC adoption model divided into briefing and visiting. The briefing process was conducted by conducting an FGD by the PCC team to determine the therapy for each patient based on the patient's medical record. Each profession provides input according to their professional competence in order to help doctors determine the best therapy, reduce the risk of unwanted events, and consider the conditions and special needs of each patient. Then the PCC team will visit each patient. All members of the PCC team provide input/education to patients directly in accordance with the conditions and needs of the patient. Visiting process in patients cataract surgery is carried out before patients undergoing surgery, including introduction, education, consultation, and informed consent. The PCC team consists of ophthalmologists, nurses and pharmacists.

Then the data is analyzed with Paired T-Test and Independent T-Test through SPSS version 21 application.

\section{RESULT AND DISCUSSION}

\section{Clinic Profile}

Ayu Siwi Eye Clinic was established on August 17, 2017, which is one of the Main Clinics in Nganjuk city, located on Jl. Veteran I / No. 16, Mangundikaran, Nganjuk. Ayu Siwi Eye Clinic is equipped with 3 examination rooms, 2 operating rooms, 1 pharmacy, and 1 optical.

Ayu Siwi Eye Clinic is one of the business units of a legal entity named PT Netra Jalin Mitra. The clinic building stands on an area of $1.770 \mathrm{~m} 2$, with the permission of the Health Office Number 503/608/411.308/2018.

This study involved 60 respondents who met the inclusion and exclusion criteria, which consisted of 29 
(48.33\%) men and 31 (51.67\%) women. The characteristics of the respondents attached to this study were gender, age, education, occupation, and history of cataract surgery.

\section{Respondents Characteristics}

Based on age (Table 1), respondents aged $\leq 50$ years were 5 people (8.33\%), aged 51-55 years were 10 people (16.67\%), aged 56-60 years were 11 people (18.33\%), aged
61-65 were 18 people (30\%), aged 66-70 years were 6 people $(10 \%)$ and $>70$ years were 10 people $(16.67 \%)$.

In table 1 , it is known that most respondents work as farmers as many as 29 people $(48.33 \%) .14$ respondents $(23.33 \%)$ were housewives, 7 respondents $(11.67 \%)$ became self-employed, 4 respondents $(6.67 \%)$ did not work, and there were 1 respondent (1.67\%) who worked as civil servants, private employees, drivers, village officials, masons and helpers.

Table 1. Responden characteristics.

\begin{tabular}{|c|c|c|}
\hline Responden Characteristics & $\mathbf{N}$ & $\%$ \\
\hline \multicolumn{3}{|l|}{ Sex } \\
\hline Men & 29 & 48.33 \\
\hline Women & 31 & 51.67 \\
\hline \multicolumn{3}{|l|}{ Age (years) } \\
\hline$\leq 50$ & 5 & 8.33 \\
\hline $51-55$ & 10 & 16.67 \\
\hline $56-60$ & 11 & 18.33 \\
\hline $61-65$ & 18 & 30 \\
\hline $66-70$ & 6 & 10 \\
\hline$>70$ & 10 & 16.67 \\
\hline \multicolumn{3}{|l|}{ Education } \\
\hline Uneducated & 12 & 20 \\
\hline Elementary & 31 & 51,67 \\
\hline Junior High & 7 & 11,67 \\
\hline High & 9 & 15 \\
\hline Diploma & 0 & 0 \\
\hline Bachelor & 1 & 1,67 \\
\hline \multicolumn{3}{|l|}{ Profession } \\
\hline Unwork & 4 & 6,67 \\
\hline Farmer & 29 & 48,33 \\
\hline Housewife & 14 & 23,33 \\
\hline Civil servants & 1 & 1,67 \\
\hline Private Employees & 1 & 1,67 \\
\hline Enterpreneur & 7 & 11,67 \\
\hline Driver & 1 & 1,67 \\
\hline Village officials & 1 & 1,67 \\
\hline Bricklayer & 1 & 1,67 \\
\hline Maid & 1 & 1,67 \\
\hline \multicolumn{3}{|l|}{ History of cataract surgery } \\
\hline Yes & 15 & 25 \\
\hline No & 45 & 75 \\
\hline
\end{tabular}

Historical data on cataract surgery showed that $75 \%$ of respondents (45 people) had never had cataract surgery and $25 \%$ of respondents (15 people) had cataract surgery in their other eyes. $(9.09 \%)$.

\section{Validity and Reliability Test}

The validity test of the SAI questionnaire and SERVQUAL modification was carried out by Madiana and Rosa (2018) in a study entitled Effectiveness of Patient Centered Care in Reducing Anxiety Levels and Increasing Satisfaction on Post-Cesarean Patient Section Patient. 
Based on the results of validity test that has been done on both instruments, item question instrument SAI which can be used to assess anxiety in this research is 14 items with $\mathrm{R}$ value count $0.475-0.738$. While the satisfaction instrument that SERVQUAL has 20 items that are valid with $R$ count $0.451-0.909$.

For reliability tests of both instruments, Cronbach's Alpha values of SAI and SERVQUAL were 0.942 and 0.955 , respectively. This indicates that both instruments are reliable.

Table 2. Validity and reliability test ${ }^{35}$.

\begin{tabular}{lclr}
\hline $\begin{array}{c}\text { Item } \\
\text { Validity Test }\end{array}$ & R table & R count & Item \\
\hline SA-I & & & \\
SERVQUAL & 0.444 & $0.475-0.738$ & 14 \\
Item Reliability & Standard & Cronbach's & Item \\
Test & & Alpha & \\
SA-I & 0.630 & 0.942 & 20 \\
SERVQUAL & 0.630 & 0.955 & 22 \\
\hline
\end{tabular}

\section{Data Analyzed}

Comparison of SAI before and after PCC in the intervention group respondents were analyzed using the Paired T-Test, with the results showing that there were significant differences between the level of anxiety before and after the PCC intervention with a significance value of $0.000(\mathrm{p}<0.05)$

Table 3. Result of data analyzed anxiety and satisfaction level

\begin{tabular}{lll}
\hline Data Analyzed & Sig (2-tailed) & $\begin{array}{l}\text { Effect } \\
\text { Size }\end{array}$ \\
\hline $\begin{array}{l}\text { Anxiety level before \&after } \\
\text { PCC }\end{array}$ & 0.000 & 2.59 \\
$\begin{array}{l}\text { Anxiety level between 2 groups } \\
\text { Satisfaction level between } 2 \\
\text { groups }\end{array}$ & 0.000 & 4.31 \\
\hline
\end{tabular}

Source: primary data processed

Comparison of SAI data between the two groups of respondents was analyzed using the Independent T-Test, with the results showing that there were significant differences between the anxiety level of the intervention group and the control group with a significance value of $0,000(\mathrm{p}<0.05)$.

Based on the calculation of Effect Size using the formula from Cohen, it was found that PCC has a strong effect in reducing the level of anxiety with sizes 2.59 and 4.31 (> 1.00), and PCC has an average effect in increasing patient satisfaction with a size of $0.56(0.5-0.8)$. is then processed using the Independent T-Test.

\section{Discussion}

This research is a quantitative analytic study with a quasi-experimental approach to pre- and post-test design, to analyze the effectiveness of PCC in reducing anxiety and increasing the satisfaction of patients with cataract surgery. Until now, researchers have not found a similar study. However, there are several studies that are like to this study.

This study shows the strong effect of PCC on reducing anxiety levels in patients with cataract surgery. These results were also obtained by Parveen et al. (2016) who only examined the effect of preoperative education on reducing anxiety levels in patients with cataract surgery. Several other studies also mentioned that PCC can reduce anxiety and death 19

This study also showed a significant difference between the patient satisfaction in the PCC intervention group and the control group. The effectiveness of PCC on improving the satisfaction of patients with cataract surgery was obtained by the average effect. Choi and Greenberg (2018) also identified significant positive findings in patients who received educational interventions, namely: 1). overall satisfaction with service, 2). cooperation, 3). compliance with postoperative self-care activities, and 4). the number of days between returning from the hospital and the time of first control. Several other studies also found that preoperative education was associated with a decrease in anxiety levels, a decrease in the number of complications, a decrease in length of stay (LOS), a reduction in pain medication, and an increase in satisfaction ${ }^{23}$.

This research can work well without significant obstacles. This can happen because researchers have explained broadly to the owner / commissioner and director of the background and description of the implementation of the research and its benefits to the clinic and patients. After a common vision of research, the board of commissioners and directors then gave direction and understanding to the executive managers. When the research is ready to begin, the researcher conducts a FGD together with the executive management regarding the stages of the research. Support from all service components in the clinic and good collaboration with researchers made the research run smoothly. In addition, with the number of cataract surgery patients per day of no more than 10 people, the process of 
collecting data through questionnaires and also the process of visiting can be carried out well.

\section{CONCLUSION}

There were significant differences in the level of anxiety and patient satisfaction between the PCC intervention group and the control group. The results showed that PCC was very effective in reducing the anxiety level of patients with cataract surgery, and PCC was quite effective in improving the satisfaction of patients with cataract surgery.

\section{REFERENCE}

1. Allen D, Vasavada A. Cataract and surgery for cataract. BMJ [Internet]. 2006 Jul 15 [cited 2018 Sep 23];333(7559):128-32. Available from: http://www.ncbi.nlm.nih.gov/pubmed/16840470

2. Anderson DF, Dhariwal M, Bouchet C, Keith MS. Global prevalence and economic and humanistic burden of astigmatism in cataract patients: a systematic literature review. Clin Ophthalmol [Internet]. 2018 [cited 2018 Sep 8];12:439-52. Available from: http://www.ncbi.nlm.nih.gov/pubmed/29563768

3. Gianino MM, Lenzi J, Bonaudo M, Fantini MP, Siliquini R, Ricciardi $\mathrm{W}$, et al. The switch between cataract surgical settings: Evidence from a time series analysis across $20 \mathrm{EU}$ countries. Madigan M, editor. PLoS One [Internet]. 2018 Feb 28 [cited 2018 Sep 23];13(2):e0192620. Available from: http://dx.plos.org/10.1371/journal.pone.0192620

4. Nijkamp MD, Ruiter RAC, Roeling M, Van Den Borne B, Hiddema F, Hendrikse F, et al. Factors related to fear in patients undergoing cataract surgery: a qualitative study focusing on factors associated with fear and reassurance among patients who need to undergo cataract surgery. Patient Educ Couns [Internet]. 2002 [cited 2018 Sep 25];47:265-72. Available from: https://s3.amazonaws.com/academia.edu.documents/5 355568/artikel_fear.pdf?AWSAccessKeyId=AKIAIW OWYYGZ2Y53UL3A\&Expires $=1537894279 \&$ Signat ure $=\mathrm{E} 8 \mathrm{qDb}$ 9Btt9FC1lhVA9IDE6n8m2E\%3D\&respon se-content-disposition $=$ inline $\% 3 \mathrm{~B}$ filename\%3DFactors_related_to_fear_in_patients

5. Ramke J, Gilbert CE, Lee AC, Ackland P, Limburg H, Foster A. Effective cataract surgical coverage: An indicator for measuring quality-of-care in the context of Universal Health Coverage. 2017 [cited 2018 Sep 16]; Available from: http://www.raabdata.

6. World Health Organization. VISION 2020 [Internet]. 2009 [cited 2018 Sep 8]. Available from: http://apps.who.int/iris/bitstream/handle/10665/206523 /B4317.pdf?sequence $=1 \&$ isAllowed $=y$

7. World Health Organization. Universal eye health: a global action plan 2014-2019. [Internet]. 2013 [cited 2018 Sep 8]. Available from: www.who.int/about/licensing/copyright_form/en/inde x.html

8. Das T. Blindness and Visual Impairment Profile and Rapid Assessment of Avoidable Blindness in South East Asia: Analysis of New Data. 2017 APAO Holmes Lecture. Asia-Pacific J Ophthalmol. 2018;

9. Astbury N. A hand to hold: communication during cataract surgery. Eye [Internet]. 2004 Feb 5 [cited 2018 Sep 8];18(2):115-6. Available from: http://www.nature.com/articles/6700569

10. Parveen A, Ellahi R, Sultana S, Tahir M, Khatoon T. Effect of Pre-Operative Education on Level of Anxiety in Patients Undergoing Cataract Surgery. J Islam Med Dent Coll [Internet]. 2016 [cited 2018 Sep 13];5(4):192-4. Available from: http://jimdc.org.pk/index.php/JIMDC/article/view/128

11. Nijkamp MD, Kenens CA, Dijker AJM, Ruiter RAC, Hiddema F. Determinants of surgery related anxiety in cataract patients. Br J Ophthalmol [Internet]. 2004 [cited 2018 Sep 14];88:1310-4. Available from: www.rivm.nl

12. Ramirez DA, Brodie FL, Rose-Nussbaumer J, Ramanathan S. Anxiety in patients undergoing cataract surgery: a pre- and postoperative comparison. Clin Ophthalmol [Internet]. 2017 [cited 2018 Sep 13];11:1979-86. Available from: http://www.ncbi.nlm.nih.gov/pubmed/29184388

13. Marback R, Temporini E, Kara Júnior Marback NR, Júnior K. Clinical Sciences Emotional Factors prior to Cataract Surgery. Clinics [Internet]. 2007 [cited 2018 Sep 17];62(4):433-41. Available from: http://www.scielo.br/pdf/clin/v62n4/a10v62n4.pdf

14. Tzelepis F, Sanson-Fisher RW, Zucca AC, Fradgley EA. Measuring the quality of patient-centered care: why patient-reported measures are critical to reliable assessment. Patient Prefer Adherence [Internet]. 2015 [cited 2018 Oct 1];9:831-5. Available from: http://www.ncbi.nlm.nih.gov/pubmed/26150703

15. Fix GM, VanDeusen Lukas C, Bolton RE, Hill JN, Mueller N, LaVela SL, et al. Patient-centred care is a 
way of doing things: How healthcare employees conceptualize patient-centred care. Heal Expect. 2018;21(1).

16. Barry MJ, Edgman-Levitan S. Shared decision making - the pinnacle of patient-centered care. $\mathrm{N}$ Engl J Med. 2012;

17. Liberati EG, Gorli M, Moja L, Galuppo L, Ripamonti S, Scaratti G. Exploring the practice of patient centered care: The role of ethnography and reflexivity. Soc Sci Med [Internet]. 2015 [cited 2018 Sep 7];133:e82-92. Available from: http://dx.doi.org/10.1016/j.socscimed.2015.03.050

18. Jardien-Baboo S, van Rooyen D, Ricks E, Jordan P. Perceptions of patient-centred care at public hospitals in Nelson Mandela Bay. Heal SA Gesondheid [Internet]. 2016 Dec [cited 2018 Sep 24];21:397-405. Available from: http://linkinghub.elsevier.com/retrieve/pii/S102598481 6300114

19. Epstein RM, Fiscella K, Lesser CS, Stange KC. Why The Nation Needs A Policy Push On Patient-Centered Health Care. Health Aff [Internet]. 2010 Aug 2 [cited 2018 Sep 21];29(8):1489-95. Available from: http://www.healthaffairs.org/doi/10.1377/hlthaff.2009. 0888

20. Epstein RM, Street RL. The values and value of patient-centered care. Annals of Family Medicine. 2011;

21. Vest JR, Bolin JN, Miller TR, Gamm LD, Siegrist TE, Martinez LE. Medical Homes: \&quot; Where You Stand on Definitions Depends on Where You Sit\&quot; Med Care Res Rev [Internet]. 2016 [cited 2018 Sep 21];67(4):393-411. Available from: http://mcr.sagepub.com

22. Delaney LJ. Patient-centred care as an approach to improving health care in Australia. Collegian [Internet]. 2018 [cited 2018 Sep 14];25:119-23. Available from: https://doi.org/10.1016/j.colegn.2017.02.005

23. Hobbs JL. A Dimensional Analysis of PatientCentered Care. 2009;58(1):52-62.

24. Meterko M, Wright S, Lin H, Lowy E, Cleary PD. Mortality among Patients with Acute Myocardial Infarction: The Influences of Patient-Centered Care and Evidence-Based Medicine. Health Serv Res [Internet]. 2010 [cited 2018 Sep 14]; Available from: https://www.ncbi.nlm.nih.gov/pmc/articles/PMC29655 00/pdf/hesr0045-1188.pdf

25. McMillan A. Patient-Centered Approaches to Health
Care: A Systematic Review of Randomized Controlled Trials Copyright Statement. 2013 [cited 2018 Sep 21]; Available from: http://hdl.handle.net/10072/55958

26. Suhonen R, Välimäki $M$, Leino-Kilpi $H$. "Individualised care" from patients', nurses' and relatives' perspective - a review of the literature. Int J Nurs Stud [Internet]. 2002 Aug [cited 2018 Sep 24];39(6):645-54. Available from: http://linkinghub.elsevier.com/retrieve/pii/S002074890 2000044

27. Morgan SS, Yoder L. A Concept Analysis of PersonCentered Care On behalf of: American Holistic Nurses Association can be found at: Journal of Holistic Nursing Additional services and information for. $\mathrm{J}$ Holist Nurs [Internet]. 2011 [cited 2018 Sep 24];20. Available

from: http://jhn.sagepub.com/http://jhn.sagepub.com/content /early/2011/07/15/0898010111412189http://jhn.sagep ub.com/cgi/alertsEmailAlerts:http://jhn.sagepub.com/

28. Cheraghi MA, Esmaeili M, Salsali M. Seeking Humanizing Care in Patient-Centered Care Process. Holist Nurs Pract [Internet]. 2017 [cited 2018 Sep 16];31(6):359-68. Available from: http://insights.ovid.com/crossref?an $=00004650$ 201711000-00002

29. Ogden K, Barr J, Greenfield D. Determining requirements for patient-centred care: a participatory concept mapping study. BMC Health Serv Res [Internet]. 2017 Dec 28 [cited 2018 Sep 21];17(1):780. Available from: https://bmchealthservres.biomedcentral.com/articles/1 0.1186/s12913-017-2741-y

30. Robinson JH, Callister LC, Berry JA, Dearing KA. Patient-centered care and adherence: Definitions and applications to improve outcomes. J Am Acad Nurse Pract [Internet]. 2008 Dec 1 [cited 2018 Sep 28];20(12):600-7. Available from: http://doi.wiley.com/10.1111/j.17457599.2008.00360.x

31. Weiner SJ, Schwartz A, Sharma G, Binns-Calvey A, Ashley N, Kelly B, et al. Patient-Centered Decision Making and Health Care Outcomes. Ann Intern Med [Internet]. 2013 Apr 16 [cited 2018 Sep 24];158(8):573. Available from: http://annals.org/article.aspx?doi=10.7326/0003-4819158-8-201304160-00001

32. Esmaeili M, Cheraghi MA, Salsali M. Explaining the Context of Patient-Centered Care in Critical Care Units. J Holist Nurs Midwifery [Internet]. 2017 Oct 15 
[cited 2018 Sep 7];27(3):17-26. Available from: http://hnmj.gums.ac.ir/browse.php?a_id=913\&sid=1\& slc_lang=en\&html=1

33. Poochikian-Sarkissian S, Sidani S, Ferguson-Pare M, Doran D. Examining the relationship between patientcentred care and outcomes. Can J Neurosci Nurs [Internet]. 2010 [cited 2018 Sep 23];32(4):14-21. Available from: www.accesscopyright.ca

34. Bertakis KD, Azari R. Patient-Centered Care is Associated with Decreased Health Care Utilization. J Am Board Fam Med [Internet]. 2011 May 1 [cited 2018 Sep 24];24(3):229-39. Available from: http://www.jabfm.org/cgi/doi/10.3122/jabfm.2011.03. 100170

35. Madiana F, Rosa EM. Efektifitas Patient Centered Care dalam Menurunkan Tingkat Kecemasan dan Meningkatkan Kepuasan Pasien Pasca Cesarian Section. 2018.

36. Jayadevappa R, Chhatre S. Patient Centered Care-A Conceptual Model and Review of the State of the Art [Internet]. Vol. 4, The Open Health Services and Policy Journal. 2011 [cited 2018 Sep 14]. Available from:

https://benthamopen.com/contents/pdf/TOHSPJ/TOH SPJ-4-15.pdf

37. Raja S, Hasnain M, Vadakumchery T, Hamad J, Shah R, Hoersch M. Identifying Elements of PatientCentered Care in Underserved Populations: A Qualitative Study of Patient Perspectives. Gupta V, editor. PLoS One [Internet]. 2015 May 19 [cited 2018 Sep 14];10(5):e0126708. Available from: http://dx.plos.org/10.1371/journal.pone.0126708

38. Haley B, Heo S, Wright P, Barone C, Rao Rettiganti
M, Anders M. Relationships among active listening, self-awareness, empathy, and patient-centered care in associate and baccalaureate degree nursing students. NursingPlus Open. 2017;3.

39. Talley-Rostov A. Patient-centered care and refractive cataract surgery. Curr Opin Ophthalmol [Internet]. 2008 Jan [cited 2018 Sep 23];19(1):5-9. Available from:

https://insights.ovid.com/crossref?an=00055735200801000-00003

40. Choi AR, Greenberg PB. Patient education strategies in cataract surgery: A systematic review. J Evid Based Med [Internet]. 2018 May [cited 2018 Sep 23];11(2):71-82. Available from: http://doi.wiley.com/10.1111/jebm.12297

41. Nijkamp MD, Nuijts RMMA, Van Den Borne B, Webers CAB, Van Der Horst F, Hendrikse F. Determinants of patient satisfaction after cataract surgery in 3 settings. J Cataract Refract Surg [Internet]. 2000 [cited 2018 Sep 26];26:1379-88. Available from: https://s3.amazonaws.com/academia.edu.documents/5 355444/artikel_Satisfaction.pdf?AWSAccessKeyId=A KIAIWOWYYGZ2Y53UL3A\&Expires $=1537904096$ $\&$ Signature $=$ VfrWwMQ\%2FBhW7hj9hPAsP1 quza $7 w$ $\% 3 \mathrm{D} \&$ response-content-disposition $=$ inline $\% 3 \mathrm{~B}$ filename\%3DDeterminants_of_patient_

42. Pager CK. Randomised controlled trial of preoperative information to improve satisfaction with cataract surgery. Br J Ophthalmol [Internet]. 2005;89(1):10-3. Available from: http://bjo.bmj.com/cgi/doi/10.1136/bjo.2004.048637 